\title{
PENGARUH PENGGUNAAN APLIKASI GAME PADA SMARTPHONE TERHADAP HASIL BELAJAR MAHASISWA PRODI PGSD STKIP PGRI TRENGGALEK
}

\author{
Anis Jannatul Firdausi \\ Prodi PGSD, STKIP PGRI Trenggalek, Indonesia \\ Email: anisjannatulf@gmail.com \\ Efi Ika Febriandari \\ Prodi PGSD, STKIP PGRI Trenggalek, Indonesia \\ Email: efi.ika.f@gmail.com \\ Angga Setiawan \\ Prodi PGSD, STKIP PGRI Trenggalek, Indonesia \\ Email: anggasetiawan25.as@gmail.com
}

\begin{abstract}
Absract:
The purpose of this study is to find out whether there is an influence of the use of game applications on smartphones on the learning outcomes of PGSD STKIP PGRI Trenggalek student learning outcomes, by using quantitative research methods with non-experimental research types or Ex-postfacto. Data obtained by distributing questionnaires through google form with the aim to determine the effect of using game applications on smartphones (independent variables) and documentation to determine student learning outcomes (dependent variable). After the data is collected, it is analyzed by the simple linear regression hypothesis test. The result of analyzing the data it is known that there is a significant influence with the results of $r$ count $=7.774$ and consulted with the value of $t$ table $=1.699$ with a confidence level of $95 \%$. While the influence of variable $X$ (the use of game applications on smartphones) on the $Y$ variable (learning outcomes) was $49.4 \%$. With these results, the alternative hypothesis is accepted and the null hypothesis is rejected. In other words it can be concluded that there is a significant influence on the use of game applications on smartphones on the learning outcomes of PGSD STKIP PGRI Trenggalek student learning outcomes. Keywort: Gamev App, Learning, Students.
\end{abstract}

\begin{abstract}
Abstrak
Penelitian ini bertujuan untuk mengetahui apakah pengaruh penggunaan aplikasi game pada smartphone terhadap hasil belajar mahasiswa prodi PGSD STKIP PGRI Trenggalek, dengan menggunakan metode penelitian kuantitatif dengan jenis penelitian non eksperimen atau Ex-postfacto. Data dikumpulkan dengan menggunakan teknik angket melalui google form dengan tujuan untuk mengetahui pengaruh penggunaan aplikasi game pada smartphone (variabel bebas) dan dokumentasi dengan tujuan untuk mengetahui hasil belajar mahasiswa (variabel terikat). Setelah data
\end{abstract}


terkumpul, peneliti menggunakan analisis dengan uji hipotesis regresi linier sederhana. Hasil dari analisis data diketahui bahwa adanya pengaruh yang cukup signifikan dengan hasil $r$ hitung $=7,774$ dan dikonsultasikan dengan nilai $\mathrm{t}$ tabel $=1,699$ dengan taraf kepercayaan 95\%. Sedangkan besar pengaruh variabel $X$ (penggunaan aplikasi game pada smartphone) terhadap variabel Y (hasil belajar) sebesar 49,4\%. Dengan hasil tersebut, hipotesis alternatif diterima dan hipotesis nihil ditolak. Kata lainnya dapat disimpulkan bahwa ada pengaruh yang signifikan antara penggunaan aplikasi game pada smartphone terhadap hasil belajar mahasiswa prodi PGSD, STKIP PGRI Trenggalek.

Kata kunci: Aplikasi Game, Belajar, Mahasiswa.

\section{Pendahuluan}

Hasil belajar tidak dapat dipisahkan dari kegiatan belajar, karena belajar merupakan suatu proses dalam pembelajaran, sedangkan hasil belajar adalah kemampuan yang dapat diperoleh setelah selesai melakukan kegiatan pembelajaran dan dilakukan setelah kegiatan belajar dilakukan. ${ }^{1}$ Dalam konteksnya, hasil belajar juga dapat dipengaruhi oleh beberapa faktor. Berdasarkan observasi yang dilakukan pada hari Senin, 23 Desember 2019 terhadap mahasiswa Prodi PGSD di STKIP PGRI Trenggalek, mayoritas mahasiswa mempunyai smartphone dengan tujuan agar mudah untuk belajar dan mencari informasi melalui internet. Selain internet, yang sangat disukai mahasiswa yaitu bermain aplikasi game pada smartphone. Mereka bermain game dimana dan kapan pun yang ia suka, baik ketika mengisi waktu luang, gabut bahkan saat perkuliahan berlangsung sehingga membuat mahasiswa tidak fokus terhadap apa yang telah diajarkan dosen dan hasil belajar yang didapatkannya kurang maksimal.

Penelitian ini didukung oleh beberapa penelitian sebelumnya yang dilakukan oleh Pratama yang berjudul "Hubungan Kecanduan Bermain Game Online Pada Smartphone (Mobile Online Games) Terhadap Prestasi Akademik Mahasiswa Angkatan 2013 Fakultas Kedokteran Universitas

\footnotetext{
${ }^{1}$ Widiyanto, B. 2020. Penerapan Model Pembelajaran Interaktif dengan Media Miniatur Untuk Peningkatan Hasil Belajar IPA Sekolah Dasar. Bidayatuna: Jurnal Pendidikan Guru Mandrasah Ibtidaiyah, 3(1), 47-68. doi:10.36835/bidayatuna.v3i01.516
} 
Lampung" yang menunjukkan bahwa terdapat korelasi negatif kecanduan bermain game online pada smartphone terhadap prestasi akademik mahasiswa angkatan 2013 Fakultas Kedokteran Universitas Lampung. ${ }^{2}$ Penelitian lain juga dilakukan oleh Rachmawati, P., dkk yang berjudul "Pengaruh Penggunaan Gadget Terhadap Hasil Belajar Mahasiswa Pendidikan Biologi Angkatan 2013 FKIP UNTAD Pada mata kuliah Desain Media Pembelajaran" menunjukkan bahwa $\mathrm{H}_{0}$ ditolak dan $\mathrm{H}_{1}$ diterima artinya penggunaan gadget berpengaruh terhadap hasil belajar mahasiswa pendidikan biologi angkatan 2013 FKIP UNTAD. ${ }^{3}$

Berdasarkan permasalahan tersebut, peneliti melakukan suatu penelitian dengan tujuan untuk mengetahui ada atau tidaknya pengaruh penggunaan aplikasi game pada smartphone terhadap hasil belajar mahasiswa. Oleh karena itu, peneliti mengambil judul "Pengaruh Penggunaan Aplikasi Game Pada Smartphone Terhadap Hasil Belajar Mahasiswa Prodi PGSD STKIP PGRI Trenggalek".

\section{Kajian Konseptual}

Belajar merupakan sebuah proses yang dialami oleh setiap individu dan mengalami perubahan. ${ }^{4}$ Hal ini sejalan dengan pendapat yang dikemukakan oleh Hitipeuw yang mengemukakan bahwa "belajar (learning) secara umum dapat diartikan sebagai proses perubahan perilaku yang relatif menetap sebagai hasil dari pengalaman".5 Sedangkan

2 Pratama, A. S. P. 2017. Hubungan Kecanduan Bermain Game Online Pada Smartphone (Mobile Online Games) Terhadap Prestasi Akademik Mahasiswa Angkatan 2013 Fakultas Kedokteran Universitas Lampung. Skripsi. Bandar Lampung: Program Studi Pendidikan Dokter Fakultas Kedokteran Universitas Lampung Bandar Lampung.

${ }^{3}$ Rachmawati, P., Rede, A., \& Jamhari, M. 2017. Pengaruh Penggunaan Gadget Terhadap Hasil Belajar Mahasiswa Pendidikan Biologi Angkatan 2013 FKIP UNTAD Pada mata kuliah Desain Media Pembelajaran. Jurnal Ilmiah Pendidikan Biologi (Online), Volume 5 Nomor 1, 35-40, diakses 22 Pebruari 2020.

${ }^{4}$ Rachman, R. (2020). Kebijakan Pendidikan Anak Berkebutuhan Khusus di Surabaya dalam Perspektif Islam. Bidayatuna: Jurnal Pendidikan Guru Mandrasah Ibtidaiyah, 3(1), 125-143. doi:10.36835/bidayatuna.v3i01.518

${ }^{5}$ Nugroho, Y.S., Degeng, I.N. S., dan Sihkabuden, 2017, Video Pembelajaran Cooperative Learning Untuk Tenaga Pengajar. Jurnal Pendidikan (Online), 2 (3): 416-423, Malang. (http://journal.um.ac.id/index.php/jptpp/article/view/8659/4186), diakses 11 Desember 2019. 
menurut pendapat lain menyatakan bahwa belajar juga dapat diartikan suatu proses (saling keterikatan antara yang satu dengan yang lainnya) 6 yang dilakukan seorang individu untuk memperoleh perubahan perilaku baru secara keseluruhan, sebagai hasil dari pengalaman individu dan berinteraksi dengan lingkungannya. ${ }^{7}$ Dari pendapat di atas dapat disimpulkan bahwa ada 3 kata kunci untuk mendefinisikan belajar yaitu 'proses perubahan perilaku', 'relatif menetap', dan 'hasil dari pengalaman' seseorang. Perubahan perilaku yang dimaksud yaitu perubahan dalam bentuk aspek kognitif, afektif dan psikomotor. Sedangkan relatif menetap yang dimaksud disini yaitu karena banyaknya perubahan perilaku yang berlangsung singkat atau temporer yang disebabkan oleh faktor-faktor yang bukan belajar, salah satunya adalah penggunaan smartphone yang secara berlebihan. Serta hasil pengalaman yang dimaksud di atas dimaknai sebagai suatu yang dialami seseorang saat berinteraksi dengan dirinya sendiri atau lingkungan di luar dirinya yang membawa perubahan pada dirinya yang dapat ditunjukkan dengan hasil belajar. 8

Menurut pendapat yang dikemukakan oleh Nawawi dalam Sari menyatakan bahwa "hasil belajar dapat diartikan sebagai suatu tingkat keberhasilan mahasiswa dalam mempelajari materi pelajaran di sekolah yang dinyatakan dalam skor yang diperoleh dari hasil tes mengenal sejumlah materi tertentu". ${ }^{9}$ Sehingga dapat disimpulkan bahwa hasil

${ }^{6}$ Mahsun, Moch. 2019. Implementasi Total Quality Management Dalam Pelayanan Penerimaan Mahasiswa Baru Di Institut Agama Islam Syarifuddin, Prosiding Seminar Nasional Pendidikan 2019, Situbondo: UNARS https://pgsd.unars.ac.id/wpcontent/uploads /2019/10/PROSIDING-SENADIK-2019.pdf\#page $=66$

7 Rusman. 2018. Belajar dan Pembelajaran Berbasis Komputer: Mengembangkan Profesionalisme Abad 21. Bandung: Alfabeta

8 Nuhan, M. Y. G. 2016. Hubungan Intensitas Bermain Game Online Dengan Prestasi Belajar Siswa Kelas IV Sekolah Dasar Negeri Jarakan Kabupaten Bantul Yogyakarta. Jurnal Pendidikan Guru Sekolah Dasar, (Online), 6 (5): 494-501, diakses 22 Pebruari 2020.

9 Ganda Aulia, Pargito, Irma Lusi Nugraheni, 2018. Perbedaan Hasil Belajar IPS Menggunakan Internet dan Perpustakaan Di SMPN 3 Way Pengubuan Jurnal Penelitian Geografi, 2018 Vol 6 No 7, Lampung: Fakultas Keguruan dan Ilmu Pendidikan Universitas Lampung Bandar Lampung. http://jurnal.fkip.unila.ac.id/index.php/JPG/article/view/16721 diakses 11 Desember 2019. 
belajar adalah tingkat keberhasilan mahasiswa yang dapat dilihat dari berbagai aspek yaitu aspek kognitif, afektif, dan psikomotor serta dapat dinyatakan dalam skor yang diperoleh dari hasil tes mengenal sejumlah materi tertentu. Hasil belajar tersebut dapat terlihat dari terjadinya perubahan, baik persepsi, perilaku, maupun perbaikan perilaku pada saat proses pembelajaran yang diamati setelah dilakukan penilaian dengan tujuan untuk mengukur keberhasilan mahasiswa berupa nilai yang diperolehnya.

\section{Metode}

Penelitian ini dilakukan pada salah satu kampus swasta di kabupaten Trenggalek yakni STKIP PGRI trenggalek yang beralamatkan Jalan Supriadi, No.22 KP 66319 Ngares, Kecamatan Trenggalek, Kabupaten Trenggalek. Peneliti melakukan Penelitian pada tanggal 3 sampai 10 Mei 2020 dengan menyebar angket melalui google form. Penelitian yang digunakan dalam penelitian ini menggunakan penelitian kuantitatif dengan jenis penelitian non eksperimen atau Ex-postfacto, karena berhubungan dengan variabel yang telah terjadi dan mereka tidak perlu memberikan perlakuan terhadap variabel yang diteliti. Teknik pengambilan sampel yang digunakan yaitu stratifield proportional random sampling, yaitu gabungan antara sampel berstrata atau stratified sample, sample proporsi atau proportional sampel, dan sampel random atau sampel acak $^{10}$ dengan jumlah subyek penelitian sebanyak 64 mahasiswa dari seluruh total semester yang ada di prodi PGSD STKIP PGRI Trenggalek tahun akademik 2019/2020. Hasil dari sampel penelitian tersebut didapat dari peneliti dengan menggunakan rumus slovin yang tujuannya untuk menentukan ukuran sampel.

Adapun prosedur yang dilakukan peneliti dibagi menjadi tiga tahap, yaitu: pertama, tahap persiapan (pra-penelitian), meliputi:

\footnotetext{
10 Sukardi. 2012. Metodologi Penelitian Pendidikan: Kompetensi dan Praktiknya. Jakarta: PT Bumi Aksara.
} 
melakukan observasi kepada dosen, identifikasi masalah dengan membaca berbagai macam sumber, penentuan lokasi penelitian, menyusun metode dan instrumen pengumpulan data, konsultasi angket kepada dosen pembimbing sebelum angket disebar, uji valid dan reliabel instrumen kepada orang yang ahli (kompeten) dalam bidang instrumen tersebut, revisi, uji valid dan reliabel instrumen lagi sampai benar-benar valid, jika sudah dinyatakan valid dan reliabel, maka instrumen dapat diterapkan di lapangan, meminta surat izin penelitian dari kampus stkip pgri trenggalek, mengajukan surat izin penelitian ke prodi pgsd stkip pgri trenggalek, dan konsultasi dengan semua dosen yang ada di stkip pgri trenggalek.

Kedua, tahap Pelaksanaan (Penelitian), meliputi:Menyusun jadwal pelaksanaan penyebaran angket non tes baik angket kepada responden melalui google form maupun dokumentasi berupa hasil belajar mahasiswa, Membuat grup wa khusus responden dengan tujuan agar komunikasi tentang penyebaran angket non tes lebih mudah, Membagikan link angket google form yang dibuat peneliti di grup wa khusus responden, Mengumpulkan dokumentasi yang dibutuhkan peneliti terkait dengan penelitian yang dilakukan ${ }^{11}$. Sedangkan ketiga, Tahap Analisis Data (Pasca Penelitian), meliputi: Melaksanakan uji prasyarat yaitu menguji analisis normalitas data dengan bantuan program SPSS for Windows 21.0 dan Melaksanakan uji analisis data dengan menggunakan uji hipotesis regresi linier sederhana dengan bantuan program SPSS for Windows 21.0.12

Metode penelitian yang digunakan dalam penelitian ini menggunakan teknik angket melalui google form yang ditujukan kepada mahasiswa dengan tujuan untuk mengetahui pengaruh penggunaan

\footnotetext{
${ }^{11}$ Supardi, S. 2016. Metodologi Penelitian. (Online). Retrieved from http://bppsdmk.kemkes.go.id/pusdiksdmk/wpcontent/uploads/2017/08/Metodologi-Penelitian-Komprehensif.pdf. diakses 4 Juni 2020

12 Arikunto, S. 2013. Prosedur Penelitian Suatu Pendekatan Praktik. Jakarta: Rineka Cipta.
} 
aplikasi game pada smartphone (variabel bebas) dengan cara mengumpulkan dan menggali data tentang penggunaan aplikasi game pada smartphone mahasiswa PGSD STKIP PGRI Trenggalek dan dokumentasi dengan tujuan untuk mengetahui hasil belajar mahasiswa (variabel terikat) dengan cara memperoleh data tentang hasil belajar ujian tengah semester (UTS) genap mahasiswa.

Dalam penelitian ini, analisis data yang digunakan yaitu statistik inferensial karena kesimpulan yang diberlakukan untuk populasi berdasarkan data sampel tersebut. Penelitian ini menggunakan teknik analisis data inferensial sebagai berikut: Pertama, dalam uji prasyarat analisis data penelitian ini menggunakan uji normalitas dengan tujuan untuk mengetahui data apakah berdistribusi normal atau tidak. ${ }^{13}$ Karena penelitian ini datanya lebih dari 50, maka pengujian normalitasnya menggunakan Test Of Normality Kolmogorov-Smirnov dengan bantuan program bantuan SPSS for Windows 21.0. Kedua, langkah selanjutnya harus dibuktikan kebenarannya dengan menggunakan uji statistik. Dalam penelitian ini, peneliti menggunakan uji hipotesis regresi linier sederhana dengan bantuan program bantuan SPSS for Windows 21.0. Berdasarkan sifat penelitian, metode analisis dan pengambilan sampel yang sudah dijabarkan di atas, maka peneliti menggunakan statistik untuk mengetahui kesimpulan data (penyimpulan data).

\section{Hasil}

Variabel pada penelitian ini terdiri atas satu variabel bebas, yaitu penggunaan aplikasi game pada smartphone dan satu variabel terikat yaitu hasil belajar. Perhitungan pada penelitian ini dilakukan dengan bantuan SPSS 21.0 for windows. Deskripsi data variabel-variabel penelitian adalah sebagai berikut.

\footnotetext{
${ }^{13}$ Supardi, S. 2017. Statistik Penelitian Pendidikan: Perhitungan, Penyajian, Penjelasan, Penafsiran, dan Penarikan Kesimpulan. Depok: Rajawali Pers.
} 
Data variabel penggunaan aplikasi game pada smartphone diperoleh dari angket yang diberikan kepada mahasiswa sebagai responden. Jumlah pernyataan dalam angket yang diberikan terdiri dari 25 pernyataan dan disusun menggunakan skala likert atau rating scale (skala bertingkat) dengan 4 pilihan jawaban. Data angket penggunaan aplikasi game pada smartphone $(\mathrm{X})$ disajikan dalam bentuk tabel dan Gambar distribusi frekuensi di bawah ini.

Tabel 1. Distribusi Frekuensi Penggunaan Aplikasi Game Pada Smartphone

\begin{tabular}{|c|c|c|c|}
\hline Kategori & Rentang Nilai & Frekuensi & Persentase \\
\hline Sangat Tinggi & $69-85$ & 50 & $78 \%$ \\
\hline Tinggi & $52-68$ & 10 & $16 \%$ \\
\hline Sedang & $35-51$ & 0 & $0 \%$ \\
\hline Rendah & $18-34$ & 0 & $0 \%$ \\
\hline Sangat Rendah & $0-17$ & 4 & $6 \%$ \\
\hline \multicolumn{2}{|c|}{ Total } & $\mathbf{6 4}$ & $\mathbf{1 0 0} \%$ \\
\hline
\end{tabular}

Sumber: Peneliti, 2020

Penjelasan tambahan untuk variabel penggunaan aplikasi game pada smartphone $(X)$ mahasiswa Prodi PGSD STKIP PGRI Trenggalek juga disajikan dalam bentuk Gambar sebagai berikut.

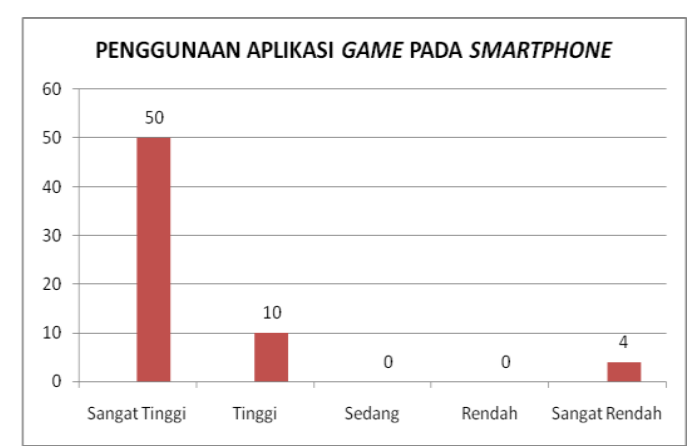

Gambar 1. Distribusi Frekuensi Penggunaan Aplikasi Game Pada Smartphone

Sumber: Peneliti, 2020

Berdasarkan tabel 1. dan gambar 1. dapat diketahui bahwa penggunaan aplikasi game pada smartphone mahasiswa prodi PGSD STKIP PGRI Trenggalek yang ada pada kategori sangat tinggi (rentang nilai 6985) terdapat 50 mahasiswa, kategori tinggi (rentang nilai 52-68) terdapat 10 mahasiswa, kategori sedang (rentang nilai 35-51) dan kategori rendah (rentang nilai 18-34) terdapat 0 mahasiswa, serta kategori sangat rendah 
(rentang nilai 0-17) terdapat 4 mahasiswa. Sehingga dapat disimpulkan penggunaan aplikasi game pada smartphone mahasiswa STKIP PGRI Trenggalek ada pada kategori sangat tinggi (rentang nilai 69-85).

Sedangkan data tentang hasil belajar diperoleh dari hasil belajar UTS (Ujian Tengah Semester) Genap berupa nilai kognitif/pengetahuan yang diperoleh dari tahap tes dalam proses pembelajaran oleh mahasiswa STKIP PGRI Trenggalek Tahun pelajaran 2019/2020. Data hasil belajar ini diperoleh dari dosen-dosen yang telah mengampu matakuliah pada semester genap tahun akademik 2019/2020 diantaranya yaitu Semester II, Semester IV, Semester VI, dan Semester VIII. Hasil dari analisa distribusi frekuensi yang diperoleh dari hasil belajar dapat disajikan dalam tabel dan Gambar distribusi frekuensi Hasil Belajar (Y) sebagai berikut.

Tabel 2.Distribusi Frekuensi Hasil Belajar

\begin{tabular}{|c|c|c|c|}
\hline Kategori & Rentang Nilai & Frekuensi & Persentase \\
\hline Sangat Baik & $91-94$ & 5 & $8 \%$ \\
\hline Baik & $87-90$ & 4 & $6 \%$ \\
\hline Cukup & $83-86$ & 8 & $13 \%$ \\
\hline Kurang Baik & $79-82$ & 6 & $9 \%$ \\
\hline Sangat Kurang Baik & $75-78$ & 26 & $41 \%$ \\
\hline Tidak Baik & $71-74$ & 10 & $15 \%$ \\
\hline Sangat Tidak Baik & $67-70$ & 5 & $8 \%$ \\
\hline \multicolumn{2}{|c|}{ Total } & $\mathbf{6 4}$ & $\mathbf{1 0 0} \%$ \\
\hline
\end{tabular}

Sumber: Peneliti, 2020

Penjelasan tambahan untuk variabel Hasil Belajar (Y) mahasiswa Prodi PGSD STKIP PGRI Trenggalek juga disajikan dalam bentuk Gambar sebagai berikut.

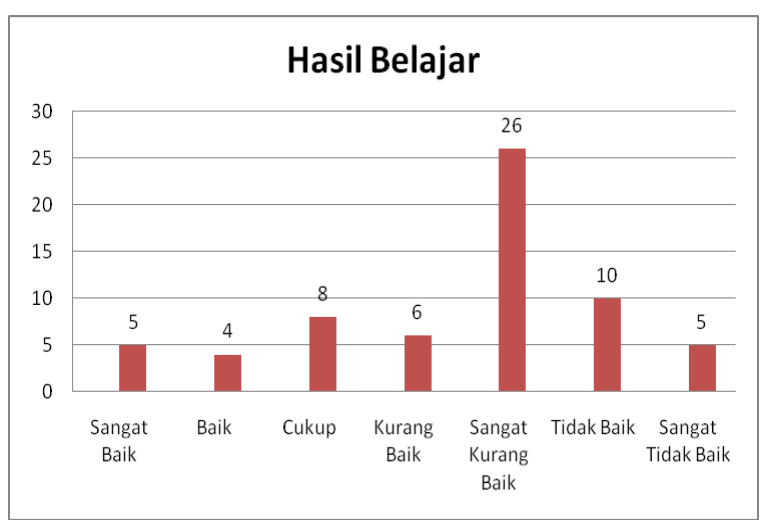


Gambar 2. Distribusi Frekuensi Hasil Belajar Sumber: Peneliti, 2020

Berdasarkan tabel 2. dan gambar 2. dapat diketahui bahwa hasil belajar mahasiswa prodi PGSD STKIP PGRI Trenggalek yang ada pada kategori sangat baik (rentang nilai 91-94) terdapat 5 mahasiswa, kategori baik (rentang nilai 87-90) terdapat 4 mahasiswa, kategori cukup (rentang nilai 83-86) terdapat 8 mahasiswa, kategori kurang (rentang nilai 79-82) terdapat 6 mahasiswa, kategori sangat kurang baik (rentang nilai 75-78) terdapat 26 mahasiswa, kategori tidak baik (rentang nilai 71-74) terdapat 10 mahasiswa, dan kategori sangat tidak baik (rentang nilai 67-70) terdapat 5 mahasiswa. Sehingga dapat disimpulkan hasil belajar mahasiswa prodi PGSD STKIP PGRI Trenggalek berada pada kategori sangat kurang baik (rentang nilai 75-78).

Pengumpulan data untuk mengetahui ada tidaknya pengaruh penggunaan aplikasi game pada smartphone yaitu dengan menggunakan teknik non tes berupa angket. Sebelum melakukan penelitian, instrumen angket terlebih dahulu harus diuji kepada dosen ahli dibidangnya yaitu Dosen PGSD yang telah dilakukan pada tanggal 1 Mei 2020. Hasil uji coba angket diperoleh bahwa angket valid dan layak digunakan yang dibantu dengan program SPSS 21.0 for windows. Untuk angket yang sudah tervalidasi selanjutnya disebar kepada responden melalui google form internet.

Uji prasyarat analisis pada penelitian ini menggunakan uji normalitas dengan tujuan untuk menguji apakah data memiliki distribusi normal sehingga dapat dilakukan analisis regresi linier sederhana untuk mengetahui pengaruh variabel bebas (penggunaan aplikasi game pada smartphone) terhadap variabel terikat (hasil belajar). Penelitian ini menggunakan normalitas Test Of Normality Kolmogorov-Smirnov dengan bantuan program SPSS 21. Berikut disajikan hasil dari pengujian normalitas, untuk lebih lengkapnya berada pada lampiran. 
Tabel 3. Uji Normalitas

One-Sample Kolmogorov-Smirnov Test

\begin{tabular}{|l|l|r|}
\hline \multicolumn{2}{|l|}{} & Unstandardized Residual \\
\hline $\mathrm{N}$ & Mean & 64 \\
\hline \multirow{2}{*}{$\begin{array}{l}\text { Normal } \\
\text { Parameters }, \mathrm{b}\end{array}$} & $\begin{array}{l}\text { Std. } \\
\text { Deviation }\end{array}$ &, 0000000 \\
\hline \multirow{2}{*}{$\begin{array}{l}\text { Most Extreme } \\
\text { Differences }\end{array}$} & Absolute & 4,75915597 \\
\cline { 2 - 3 } & Positive &, 138 \\
\cline { 2 - 3 } & Negative & ,138 \\
\hline Kolmogorov-Smirnov Z & 115 \\
\hline Asymp. Sig. (2-tailed) &, 173 \\
\hline
\end{tabular}

a. Test distribution is Normal.

b. Calculated from data.

Sumber: Peneliti, 2020.

Berdasarkan tabel 3. perhitungan uji normalitas di atas dapat diketahui bahwa nilai signifikansi penelitian ini 0,173, dimana jika signifikansi $\geq 0,05$ data berdistribusi normal, maka 0,173 >0,05. Jadi dapat disimpulkan bahwa data pada penelitian ini berdistribusi normal.

Sedangkan analisis data yang digunakan dalam penelitian ini menggunakan analisis regresi linier sederhana dengan tujuan untuk mengetahui ada tidaknya pengaruh penggunaan aplikasi game pada smartphone terhadap hasil belajar. Berikut disajikan hasil dari analisis regresi linier sederhana dalam penelitian, untuk lebih lengkapnya berada pada lampiran.

Tabel 4. Perhitungan Regresi Linier Sederhana

Coefficients $^{\mathbf{a}}$

\begin{tabular}{|c|c|c|c|c|c|c|}
\hline \multirow{2}{*}{\multicolumn{2}{|c|}{ Model }} & \multicolumn{2}{|c|}{$\begin{array}{c}\text { Unstandardized } \\
\text { Coefficients }\end{array}$} & $\begin{array}{c}\text { Standardized } \\
\text { Coefficients } \\
\end{array}$ & \multirow[t]{2}{*}{$\mathrm{T}$} & \multirow[t]{2}{*}{ Sig. } \\
\hline & & $\mathrm{B}$ & Std. Error & Beta & & \\
\hline \multirow[b]{2}{*}{1} & (Constant) & 62,104 & 2,258 & & 27,499 &, 000 \\
\hline & $\begin{array}{l}\text { Penggunaan Aplikasi } \\
\text { Game Pada Smartphone }\end{array}$ & ,244 & ,031 & ,703 & 7,774 & 000 \\
\hline
\end{tabular}

a. Dependent Variable: Hasil Belajar

Sumber: Peneliti, 2020 
Berdasarkan tabel 4. di atas dapat diketahui bahwa nilai Constant (a) sebesar 62,104, sedang nilai penggunaan aplikasi game pada smartphone (b/koefisien regresi) sebesar 0,244, sehingga persamaan regresinya dapat ditulis:

$\gamma=\alpha+b X$

$y=62,104+0,244 X$

Persamaan tersebut juga dapat diterjemahkan bahwa konstanta sebesar 62,104 mengandung arti bahwa nilai konsisten variabel penggunaan aplikasi game pada smartphone adalah sebesar 62,104. Dan koefisien regresi $X$ sebesar 0,244 yang menyatakan bahwa setiap penambahan $1 \%$ nilai penggunaan aplikasi game pada smartphone, maka nilai hasil belajar berkurang sebesar 0,244.

Cara mencari

$$
\begin{aligned}
r_{\text {tabel }} & =\left(\frac{\alpha}{2}: \mathrm{n}-\mathrm{k}-1\right) \\
& =\left(\frac{0,05}{2}: 64-1-1\right) \\
& =(0,025: 62) \\
& =1,699 \quad \text { Sumber: Peneliti, } 2020
\end{aligned}
$$

Pengambilan keputusan pada analisis regresi sederhana ini yaitu jika nilai signifikansi $<0,05$ maka dinyatakan bahwa ada pengaruh antara penggunaan aplikasi game pada smartphone $(\mathrm{X})$ terhadap hasil belajar $(\mathrm{Y})$, berdasarkan tabel 4.6 Coefficients di atas dapat diperoleh nilai signifikansi sebesar $0,000<0,05$, sehingga dapat disimpulkan bahwa variabel penggunaan aplikasi game pada smartphone $(\mathrm{X})$ berpengaruh terhadap hasil belajar (Y). Sedangkan nilai $t$ diketahui bahwa nilai $r_{\text {hitung }}$ sebesar 7,774 $>r_{\text {tabel }}$ sebesar 1,699 sehingga dapat disimpulkan bahwa penggunaan aplikasi game pada smartphone $(\mathrm{X})$ berpengaruh terhadap hasil belajar (Y). 
Analisis regresi linier sederhana ini juga dapat digunakan utuk mengetahui seberapa besar pengaruh variabel $X$ terhadap $Y$, sehingga penelitian ini dapat diketahui bahwa seberapa besar pengaruh penggunaan aplikasi game pada smartphone terhadap hasil belajar mahasiswa prodi PGSD STKIP PGRI Trenggalek Tahun Akademik 2019/2020. Berikut disajikan hasil berapa besar pengaruh variabel X terhadap $Y$, untuk lebih lengkapnya berada pada lampiran.

Tabel 5. Besar Pengaruh Variabel $X$ terhadap Variabel $Y$

Model Summary ${ }^{b}$

\begin{tabular}{|l|c|r|r|c|}
\hline $\begin{array}{l}\text { Mode } \\
1\end{array}$ & $\mathrm{R}$ & $\begin{array}{c}\mathrm{R} \\
\text { Squar } \\
\mathrm{e}\end{array}$ & $\begin{array}{c}\text { Adjuste } \\
\mathrm{d} \text { R } \\
\text { Square }\end{array}$ & $\begin{array}{c}\text { Std. Error } \\
\text { of the } \\
\text { Estimate }\end{array}$ \\
\hline 1 &, $703^{\mathrm{a}}$ &, 494 &, 485 & 4,79738 \\
\hline
\end{tabular}

a. Predictors: (Constant), Penggunaan

Aplikasi Game Pada Smartphone

b. Dependent Variable: Hasil Belajar

Sumber: Peneliti, 2020

Berdasarkan tabel 5. di atas menunjukkan bahwa besarnya nilai korelasi/hubungan $(R)$ yaitu 0,703 . Sedangkan koefisien determinasi $(R$ Square) sebesar 0,494 dikalikan 100\% sama dengan 49,4\%, artinya besar pengaruh variabel bebas (penggunaan aplikasi game pada smartphone) terhadap variabel terikat (hasil belajar) adalah sebesar $49,4 \%$.

\section{Pembahasan}

Smartphone sekarang sudah menjadi permainan modern yang banyak dimainkan di Indonesia. Game yang ada di smartphone merupakan game yang ada saat ini sebagai media hiburan. Game ini lebih berpengaruh dari pada game yang ada dikomputer karena game ini sekarang berada dalam genggaman serta lebih mudah dimainkan dimanapun dan kapanpun seseorang berada.

Di dalam game ini, para pemain bisa berinteraksi dengan NPC atau karakter pemain lain yang jumlahnya sangat banyak (tergantung kemampuan server game dalam menampung pemain) dan begitu 
mengasyikkan yang membuat para pemain lupa waktu, lupa diri dan halhal lain, baik yang ada dalam lingkungan seseseorang maupun lingkungan sosial sehingga interaksi hanya sebatas dengan game saja, dapat membuat kecanduan mahasiswa dan mempengaruhi jadwal rutinitas mahasiswa dalam kehidupan sehari-hari, seperti mengubah sikap mahasiswa menjadi malas belajar dan tidur tidak pada waktunya. Hal ini sejalan dengan pendapat para ahli yang menyatakan bahwa game juga memiliki sifat candu sehingga waktu mahasiswa banyak dihabiskan untuk bermain game yang dapat mempengaruhi hasil belajar mahasiswa. Contoh konkret yang terjadi di lingkungan sekolah adalah seorang mahasiswa awalnya mendapatkan prestasi yang sangat bagus, namun karena keseringan bermain game dan tidak belajar prestasi belajarnya semakin menurun. Begitu juga untuk anak yang kurang berprestasi, maka tentunya akan membuat prestasi belajarnya semakin tertinggal (Nuhan, 2016).

Berdasarkan landasan teori yang telah diungkapkan di atas, penggunaan aplikasi game pada smartphone diprediksi memiliki pengaruh dengan hasil belajar mahasiswa. Hal ini sesuai dengan penelitian yang dilakukan oleh Rachmawati, yang berjudul "Pengaruh Penggunaan Gadget Terhadap Hasil Belajar Mahasiswa Pendidikan Biologi Angkatan 2013 FKIP UNTAD Pada mata kuliah Desain Media Pembelajaran" menunjukkan bahwa $\mathrm{H}_{0}$ ditolak dan $\mathrm{H}_{1}$ diterima, artinya penggunaan gadget berpengaruh terhadap hasil belajar mahasiswa pendidikan biologi angkatan 2013 FKIP UNTAD. ${ }^{14}$

Interpretasi merupakan pembahasan temuan-temuan penelitian yang telah dilakukan dalam serangkaian kegiatan penelitian dimana bertujuan untuk menjawab masalah penelitian atau menunjuk bagaimana penelitian itu, serta menafsirkan dan mengintegrasikan temuan penelitian

\footnotetext{
${ }^{14}$ Rachmawati, P., Rede, A., \& Jamhari, M. 2017. Pengaruh Penggunaan Gadget Terhadap Hasil Belajar Mahasiswa Pendidikan Biologi Angkatan 2013 FKIP UNTAD Pada mata kuliah Desain Media Pembelajaran. Jurnal Ilmiah Pendidikan Biologi (Online), Volume 5 Nomor 1, 35-40, diakses 22 Pebruari 2020.
} 
kedalam kumpulan pengetahuan yang telah mapan sehingga akan lebih bermakna dan berguna bagi pengembangan pengetahuan atau sesuatu yang telah diteliti ke dalam kegiatan sehari-hari.

Berdasarkan hasil perhitungan regresi linier sederhana antara penggunaan aplikasi game pada smartphone dengan hasil belajar diketahui bahwa $r_{\text {hitung }}$ sebesar 7,774, kemudian dikonsultasikan dengan $r_{\text {tabel }}$ pada taraf signifikansi 5\% =1,699, maka $H_{a}$ diterima dan $H_{o}$ ditolak yang artinya bahwa $r_{\text {hitung }}$ lebih besar dari $r_{\text {tabel }}$, sehingga dapat dikatakan bahwa penggunaan aplikasi game pada smartphone mempunyai pengaruh dengan hasil belajar mahasiswa.

Penggunaan aplikasi game pada smartphone pada prinsipnya bertujuan untuk mengetahui adakah pengaruh penggunaan aplikasi game pada smartphone $(\mathrm{X})$ dengan hasil belajar $(\mathrm{Y})$ mahasiswa prodi PGSD STKIP PGRI Trenggalek Tahun Akademik 2019/2020. Pernyataan tersebut terjawab dan terbukti dari hasil uji koefisien determinasi yang menyatakan bahwa ada pengaruh antara penggunaan aplikasi game pada smartphone (variabel X) dengan hasil belajar (variabel Y) mahasiswa prodi PGSD STKIP PGRI Trenggalek Tahun Akademik 2019/2020 dan besar pengaruh variabel $X$ (penggunaan aplikasi game pada smartphone) terhadap variabel Y (hasil belajar) sebesar 49,4\%. Sehingga dapat disimpulkan bahwa kebiasaan bermain aplikasi game pada smartphone yang dilakukan oleh mahasiswa prodi PGSD STKIP PGRI Trenggalek Tahun Akademik 2019/2020, ternyata berpengaruh dengan pencapaian hasil belajar mahasiswa prodi PGSD STKIP PGRI Trenggalek. Apabila penggunaan aplikasi game pada smartphone semakin tinggi, maka hasil belajar mahasiswa semakin menurun. Begitu juga sebaliknya, apabila aplikasi game pada smartphone semakin rendah, maka hasil belajar mahasiswa semakin tinggi. 


\section{Kesimpulan}

Berdasarkan analisis data hasil penelitian dan pembahasan yang sudah dibahas di bab sebelumnya, dapat disimpulkan bahwa terdapat pengaruh yang signifikan penggunaan aplikasi game pada smartphone terhadap hasil belajar mahasiswa prodi PGSD STKIP PGRI Trenggalek Tahun Akademik 2019/2020. Adapun persamaan regresinya yaitu $y^{\prime}=62,104+0,244 X$. Hal ini menunjukkan bahwa koefisien regresi $X$ sebesar 0,244 yang menyatakan bahwa setiap penambahan $1 \%$ nilai penggunaan aplikasi game pada smartphone, maka nilai hasil belajar berkurang sebesar 0,244. Hubungan antara penggunaan aplikasi game pada smartphone terhadap hasil belajar memiliki nilai sebesar 0,494. Besarnya pengaruh penggunaan aplikasi game pada smartphone terhadap hasil belajar dilihat dari koefisien determinasi ( $R$ Square) yang dikalikan 100\%, sehingga dapat diketahui bahwa besar pengaruh penggunaan aplikasi game pada smartphone (variabel X/bebas) terhadap hasil belajar (variabel Y/terikat) adalah sebesar 49,4\%. Hal ini dapat dijadikan sebagai pertimbangan bahan evaluasi untuk pihak kampus agar mahasiswa bisa memanfaatkan aplikasi game pada smartphone dengan sebaik-baiknya sehingga mahasiswa dapat meningkatkan hasil belajar yang tinggi.

\section{Daftar Pustaka}

Arikunto, S, 2013, Prosedur Penelitian Suatu Pendekatan Praktik, Jakarta: Rineka Cipta.

Ganda Aulia, Pargito, Irma Lusi Nugraheni, 2018, Perbedaan Hasil Belajar IPS Menggunakan Internet dan Perpustakaan Di SMPN 3 Way Pengubuan, Jurnal Penelitian Geografi, 2018 Vol 6 No 7, Lampung: Fakultas Keguruan dan Ilmu Pendidikan Universitas Bandar Lampung. http://jurnal.fkip.unila.ac.id/index.php/JPG/article/view/16721, diakses 11 Desember 2019.

Mahsun, Moch. 2019. Implementasi Total Quality Management Dalam Pelayanan Penerimaan Mahasiswa Baru Di Institut Agama Islam Syarifuddin, Prosiding Seminar Nasional Pendidikan 2019, Situbondo: 
UNARS

https:/ / pgsd.unars.ac.id/wpcontent/ uploads/2019/10/PROSIDING-SENADIK2019.pdf\# page $=66$

Nugroho, dkk 2017, Video Pembelajaran Cooperative Learning Untuk Tenaga Pengajar. Jurnal Pendidikan (Online), 2 (3): 416-423, (http://journal.um.ac.id/index.php/jptpp/article/view/8659/418 6), diakses 11 Desember 2019.

Nuhan, M. Y. G, 2016, Hubungan Intensitas Bermain Game Online Dengan Prestasi Belajar Siswa Kelas IV Sekolah Dasar Negeri Jarakan Kabupaten Bantul Yogyakarta, Jurnal Pendidikan Guru Sekolah Dasar, (Online), 6 (5): 494-501, diakses 22 Pebruari 2020.

Pratama, A. S. P, 2017, Hubungan Kecanduan Bermain Game Online Pada Smartphone (Mobile Online Games) Terhadap Prestasi Akademik Mahasiswa Angkatan 2013 Fakultas Kedokteran Universitas Lampung. Skripsi, Bandar Lampung: Program Studi Pendidikan Dokter Fakultas Kedokteran Universitas Lampung Bandar Lampung.

Rachmawati, dkk, 2017, Pengaruh Penggunaan Gadget Terhadap Hasil Belajar Mahasiswa Pendidikan Biologi Angkatan 2013 FKIP UNTAD Pada mata kuliah Desain Media Pembelajaran, Jurnal Ilmiah Pendidikan Biologi (Online), Volume 5 Nomor 1, 35-40, diakses 22 Pebruari 2020.

Rachman, R. 2020. Kebijakan Pendidikan Anak Berkebutuhan Khusus di Surabaya dalam Perspektif Islam. Bidayatuna: Jurnal Pendidikan Guru Mandrasah Ibtidaiyah, 3(1), 125-143. doi:10.36835/bidayatuna.v3i01.518

Rusman, 2018, Belajar dan Pembelajaran Berbasis Komputer: Mengembangkan Profesionalisme Abad 21. Bandung: Alfabeta.

Sukardi, 2012, Metodologi Penelitian Pendidikan: Kompetensi dan Praktiknya. Jakarta: PT Bumi Aksara.

Supardi, S, 2016, Metodologi Penelitian, (Online), Retrieved from http:/ / bppsdmk.kemkes.go.id/pusdiksdmk/wpcontent/uploads/2017/08/Metodologi-PenelitianKomprehensif.pdf, diakses 4 Juni 2020.

Supardi, S, 2017, Statistik Penelitian Pendidikan: Perhitungan, Penyajian, Penjelasan, Penafsiran, dan Penarikan Kesimpulan, Depok: Rajawali Pers. 
Syafrida, R, 2014, Regulasi Diri dan Intensitas Penggunaan Smartphone Terhadap Keterampilan Sosial. Jurnal Pendidikan Usia Dini. (Online), 2 (3): 353-363. (https://media.neliti.com/media/publications/118103-IDregulasi-diri-dan-intensitas-penggunaan.pdf), diakses 26 Desember 2019.

Widiyanto, B. 2020. Penerapan Model Pembelajaran Interaktif dengan Media Miniatur Untuk Peningkatan Hasil Belajar IPA Sekolah Dasar. Bidayatuna: Jurnal Pendidikan Guru Mandrasah Ibtidaiyah, 3(1), 47-68. doi:10.36835/bidayatuna.v3i01.516 